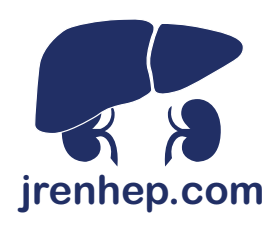

REVIEW ARTICLE

\title{
Reprogrammed Cell-based Therapy for Liver Disease: From Lab to Clinic
}

\author{
Amir Mehdizadeh ${ }^{1}$, Masoud Darabi ${ }^{2,3}$ \\ ${ }^{1}$ Liver and Gastrointestinal Diseases Research Center, Tabriz University of Medical Sciences, Tabriz, Iran; ${ }^{2}$ Stem Cell Research Center, Tabriz \\ University of Medical Sciences, Tabriz, Iran; ${ }^{3}$ Department of Biochemistry and Clinical Laboratories, Faculty of Medicine, Tabriz University of \\ Medical Sciences, Tabriz, Iran
}

\begin{abstract}
A large number of patients are affected by liver dysfunction worldwide. Liver transplantation is the only efficient treatment in a variety of enduring liver disorders including inherent and end-stage liver diseases. The generation of human functional hepatocytes in high quantities for liver cell therapy is an important goal for ongoing therapies in regenerative medicine. Reprogrammed cells are considered as a promising and unlimited source of hepatocytes, mainly because of their expected lack of immunogenicity and minimized ethical concerns in clinical applications. Despite gained advances in the reprogramming of somatic cells to functional hepatocytes in vitro, production of primary adult hepatocytes that can proliferate in vivo still remains inaccessible. As part of efforts toward translation of cell reprogramming science into clinical practice, more careful cell selection strategies should be integrated into improvement of dedifferentiation and redifferentiation protocols, especially in precision medicine where gene correction is needed. Furthermore, advances in cellular reprogramming highlight the need for developing and evaluating novel standards addressing clinical research interests in this field.
\end{abstract}

Keywords: cell therapy; gene editing; liver transplantation; regenerative medicine; stem cells

Received: 09 December 2016; Accepted after revision: 05 January 2017; Published: 03 February 2017.

Author for correspondence: Masoud Darabi, Stem Cell Research Center, Tabriz University of Medical Sciences, Tabriz 51666-15556, Iran. Email: darabim@tbzmed.ac.ir

How to cite: Mehdizadeh A et al. Reprogrammed Cell-based Therapy for Liver Disease: From Lab to Clinic. J Ren Hepat Disord 2017;1(1):20-28.

DOI: http://dx.doi.org/10.15586/jrenhep.2017.6

Copyright: Mehdizadeh A and Darabi M

License: This open access article is licensed under Creative Commons Attribution 4.0 International (CC BY 4.0).

http://creativecommons.org/licenses/by/4.0

\section{Introduction}

A large number of patients are affected by liver dysfunction worldwide. Liver transplantation is the only efficient treatment in a variety of enduring liver disorders including inherent and end-stage liver diseases. However, there is a high shortage of liver organ donors causing almost $40 \%$ of patients with high rate of mortality receiving no organ transplantation. Therefore, new strategies supporting liver transplantation are in high demand. Familial hypercholesterolemia, Crigler-Najjar syndrome type I, glycogen storage disease type 1a, urea cycle defects and congenital deficiency of coagulation factor VII, hepatitis, cirrhosis, and liver cancer are the main liver diseases having clinical indications for cell therapy (1).

There are several cell sources for human liver cell therapy, including primary hepatocytes (1), tumor cell lines (2), immortalized hepatocyte lines from normal human hepatocytes (3), liver stem cells (4), hepatocyte-like cells from bone-marrowderived stem cells (5), hepatocyte-like cells from fetal annex 
(6) and embryo (4), or reprogrammed somatic cells (7). Among them, reprogrammed cells are considered as a promising and unlimited source of hepatocytes (Figure 1), mainly because of their expected lack of immunogenicity and minimized ethical concerns in clinical applications (1). These cells can be obtained by redifferentiation of any accessible somatic cells including skin, mucosa, and urine cells. In the first stage, mature somatic cells (e.g., fibroblasts) are dedifferentiated to the pluripotent stages. Besides their full pluripotency potential, these dedifferentiated cells are able to self-renew in vitro, which means they can potentially produce sufficient source for cell-based therapies. During the second stage, pluripotent cell reservoirs are induced to differentiate into functional hepatocytes. In the case of genetic deficiency, dedifferentiated cells undergo gene-editing strategies before redifferentiation.

\section{Somatic Cell Dedifferentiation}

The concept of somatic cell dedifferentiation into pluripotent stem cells, which are capable to form the three germinal layers and to differentiate into other cell types, provides a promising approach for regenerative medicine. This dedifferentiation technique enables us to obtain donor- or patient-specific pluripotent stem cells (8). In the following section, current methods for dedifferentiation of somatic cells are briefly reviewed.

\section{Somatic cell nuclear transfer into oocyte}

The principles of this method involve in vitro removal of oocyte nucleus followed by its replacement with donor somatic nucleus. Then, cell division is stimulated by chemicals or electricity up to blastocyst stage. At this stage, cellular mass is isolated and cultured. The resulting embryonic stem (ES) cells are immunologically very identical to donor cells, and no immunosuppressant is required after transplantation to prevent their rejection. However, mitochondrial DNA from maternal oocytes could be potentially immunogenic (9). Major limitations of this method for clinical application are ethical concerns related to germ cell manipulation, chromosomal disorders in derived stem cells, low efficiency of transfer technique, and insufficient supply of human oocytes (8).

\section{Somatic cell fusion with embryonic stem cell}

An advanced method of cell fusion was developed by Cowan et al. (10) which reprogrammed human normal diploid fibroblasts into ES cells. In this method, human embryonic cells were fused with human fibroblasts, resulting in hybrid cells with stable tetraploid DNA. Characteristics of these cells were similar to human ES cells. However, before clinical application, a set of technical limitations should be resolved. The most important challenge is to abolish ES-like cells after cell fusion.

\section{Somatic cell dedifferentiation using cell extracts}

Different cell extracts can alter gene expression profile in somatic cells (11). Data obtained from experiments on $293 \mathrm{~T}$ cells, an embryonic kidney cell line, have revealed that extracts of ES cells or embryonic carcinoma cells can induce ES cell phenotype and expression of pluripotency genes. Expression of somatic gene markers such as lamin A

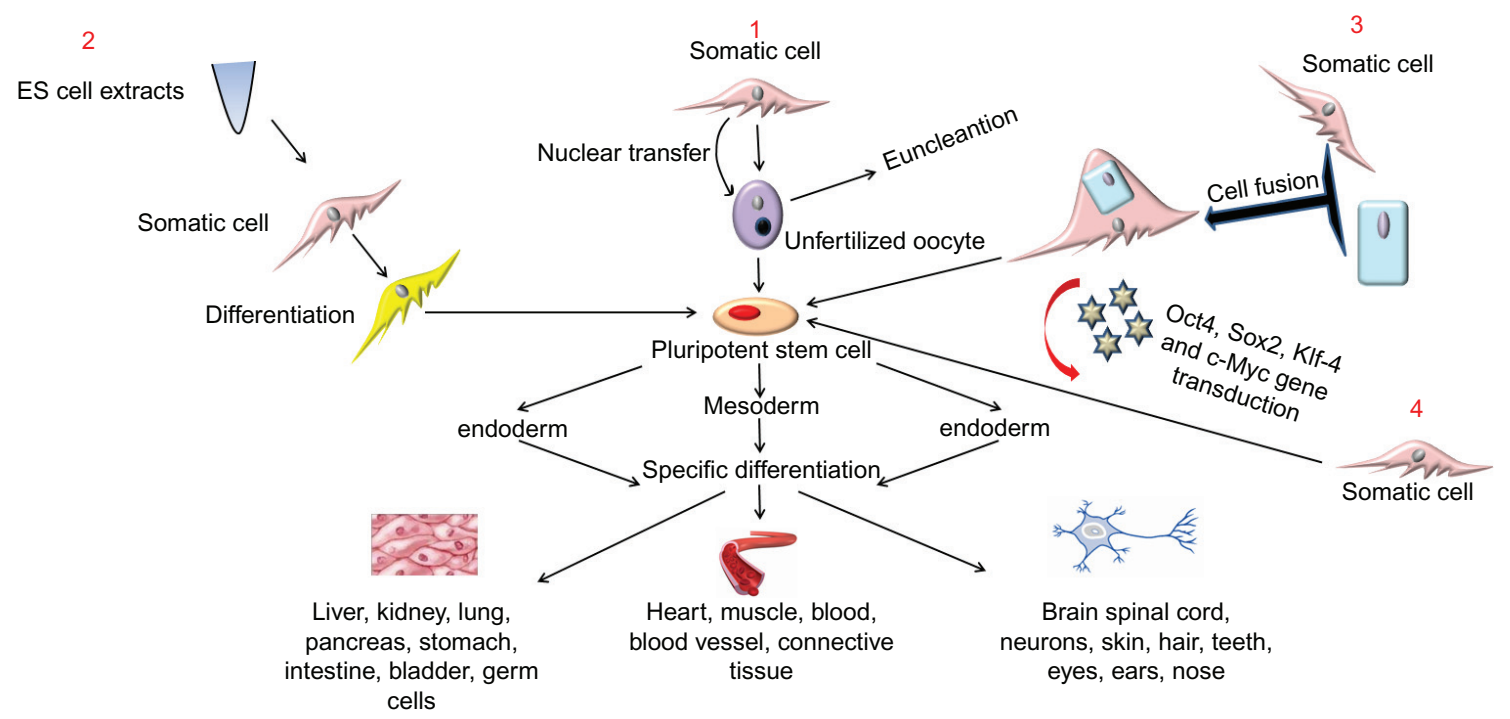

Figure 1. Approaches for creating reprogrammed cells from somatic cells. 1: Somatic cell nuclear transfer into oocyte; 2, adding embryonic stem cell (ES) extract to somatic cells; 3: somatic and ES cell fusion; and 4: transduction of pluripotency genes. Generated reprogrammed cells from each strategy can create three germ layers known as ectoderm, endoderm, and mesoderm. Induced redifferentiation of these reprogrammed cells can provide functional calls and tissues. 
was reduced after this manipulation. Besides, these cells gained the ability to differentiate into mesoderm and ectoderm lineages (12). Bru et al. (13) also reported the elevation in expression of pluripotency genes including Oct3/4, Sox2, Klf-4, and c-Myc after exposure of mouse ES cell extracts to $293 \mathrm{~T}$ cells for $48 \mathrm{~h}$. However, these cells are generally limited in pluripotency potential.

\section{Somatic cell reprogramming using pluripotency-related genes}

In 2006, the discovery of somatic cell reprogramming to induced pluripotent stem cells (iPSCs) led to a revolution in regenerative medicine (14). iPSCs are basically patient-specific pluripotent cells that are produced by inserting four genes, including Oct4, Sox2, Kfl4, and c-Myc, necessary for fibroblasts to evolve ES-like properties. Recent studies have indicated that only the presence of Oct4 gene may be sufficient to induce pluripotency in adult cells (15). In vitro, iPSCs have efficiently been used for liver tissue construction (15). Takebe et al. (16) showed that co-culture of human iPSCsderived hepatic endoderm cells with human umbilical vein endothelial cells and human mesenchymal stem cells leads to the formation of liver buds (LBs) in 3D culture condition. Furthermore, iPSCs-LBs injection to mouse resulted in dynamic vascularization. Therefore, these cells can potentially be applied in vast areas including disease modeling, tissue engineering, and drug discovery $(17,18)$.

\section{Cellular Redifferentiation to Functional Liver Cells}

The generation of human functional hepatocytes in high quantities for liver cell therapy is an important goal for ongoing therapies in regenerative medicine. Here, we introduce main practical strategies for redifferentiation of pluripotent cells to liver cells.

\section{Precision medicine: CRISPR/Cas9 genome editing}

To date, therapies based on human ES cells are associated with controversial issues related to ethical concerns in using human embryos and potential risk of immune-mediated tissue rejection. Utilization of patient's cells in order to avoid ethical concerns and rejection complications is possible by cellular reprogramming, particularly iPSCs technology (19). Based on the present protocols, fibroblasts with skin biopsy origin can be returned to pluripotent stage and serve as a renewable and autologous cellular source (20). However, the original mutation that causes disease will be present in patient-derived pluripotent stem cells. Precise correction of mutation is possible by gene-editing technique, "clustered regularly interspersed short palindromic repeats (CRISPR)/Cas9 system," which evolutionarily serves as an immune system in bacteria and archaea against virus and plasmid invasion (Figure 2). The specificity of this technique mainly depends on a guide RNA (gRNA) that can be readily reprogrammed to loci of target gene (21). Editing mutations in iPSCs derived from patients with retinitis pigmentosa was recently used

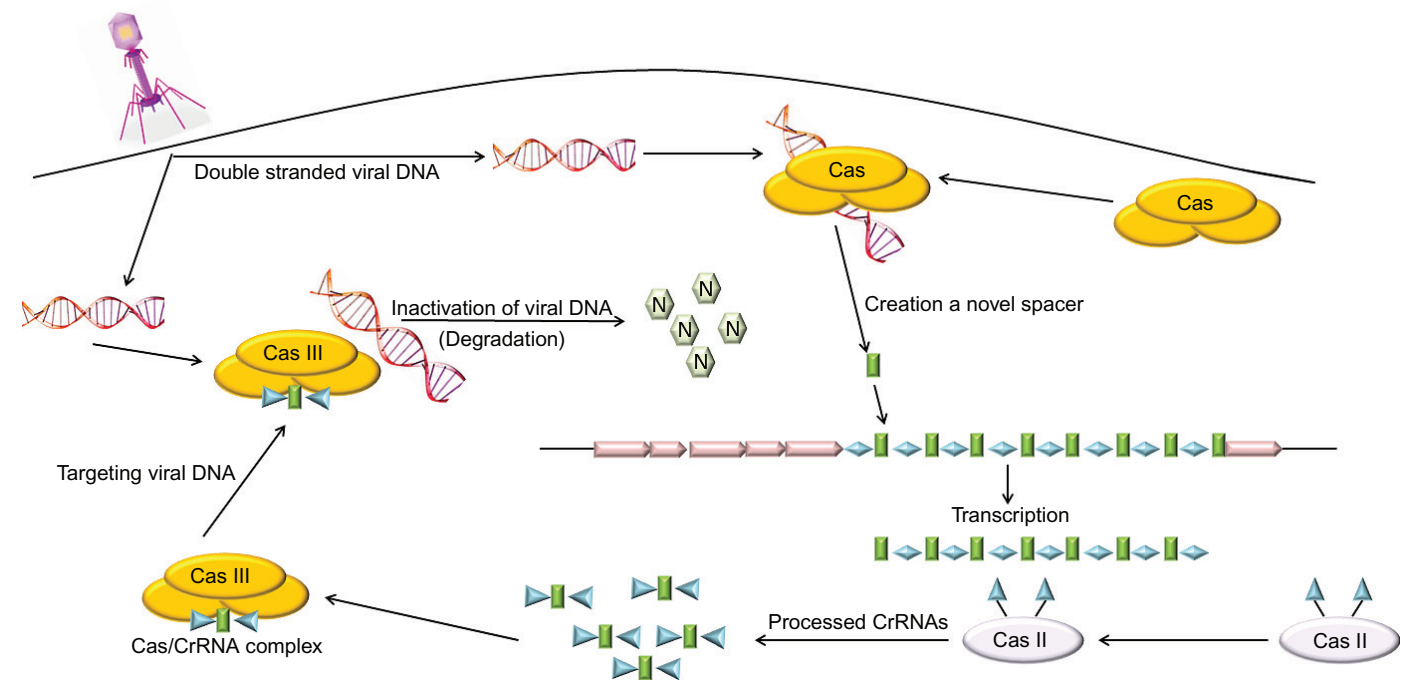

Figure 2. Schematic presentation of clustered regularly interspersed short palindromic repeats (CRISPR/Cas9) system. It is basically a bacterial adaptive immune system. When an exogenous viral or bacteriophage genome is inserted into a bacterium, CAS protein, which acts as a nuclease, detects the exogenous unmethylated genome by attachment to a 3-5 nucleotide sequence. Then, CAS protein cuts the target sequence and inserts the fragment just before 3-5 nucleotide sequence into host genome. After transcription, crispr RNAs (crRNAs) are produced which are complementary to the exogenous genome. crRNAs can recognize the exogenous genome if a viral reinfection occurs. 
through CRISPR/Cas9 approach (19), which opens a promising era in regenerative medicine and genome engineering.

\section{Cytokines and growth factors}

Hepatic regeneration is a complicated process regulated by growth factors, cytokines, transcription factors, hormones, microRNAs, metabolic pathways, and products of oxidative stress (22). The use of a specific pool of cytokines in a serumfree medium is a prerequisite for liver organogenesis step in differentiation process (23). For example, high doses of activin $A$ are widely used for endodermal induction in human pluripotent stem cells $(24,25)$. Some protocols have added low doses of serum for promoting essential effects of activin $\mathrm{A}$ in the development of endodermal induction $(26,27)$. Furthermore, fibroblast growth factor (FGF) and Wnt signaling, which play important roles in normal liver development, are also effective in endodermal induction programs $(28,29)$. Researchers have also combined bone morphogenetic protein and FGFs to promote endodermal induction specificity $(26,30)$. Hepatocyte growth factor is also widely used in hepatic differentiation of pluripotent stem cell, mainly because of its ability in developing hepatoblast proliferation, migration, and survival through c-Met as tyrosine kinase part (31). Combination of FGF10 and retinoic acid with simultaneous inhibition of activin $\mathrm{A}$ is also another effective hepatic endodermal maturation protocol (32). In addition, oncostatin, which is a member of interleukin- 6 family, in combination with glucocorticoids, can induce hepatocyte maturation $(33,34)$.

\section{Genetic and epigenetic manipulation}

Genetic manipulation for the purpose of overexpression of specific genes involved in hepatic induction is another approach in regenerative medicine. Transducing some transcription factors such as Sox17, Gata, and hepatic nuclear factor $4 \alpha$ elevates iPSC hepatic induction at specific time intervals in culture media $(35,36)$. Furthermore, epigenetic interferences have also been used to improve hepatic differentiation protocols (32). For instance, sodium butyrate, a specific inhibitor of histone deacetylase, is frequently used to differentiate pluripotent stem cells into different cell lineages including hepatocytes in higher concentrations and longer time intervals (37-39).

\section{Chemicals (small molecules)}

Recent studies have proposed novel growth-factor-free protocols for the differentiation of pluripotent stem cells (40). Siller et al. (40) introduced a three-phasic protocol including 1) inhibition of glycogen synthase kinase 3 by CHIR 99021 for definitive endoderm induction, 2) hepatic specification through dimethyl sulfoxide treatment, and 3) using dexamethasone and dihexa, a hepatocyte growth factor receptor agonist, to differentiate pluripotent stem cells into hepatocyte-like cells. Zhu et al. (41) also used a cocktail of small molecules for incompletely reprogrammed human fibroblast cells to hepatocytes. In addition, Shan. et al. (42) identified 12,480 small molecules in a liver platform, and they classified them into two large groups: functional proliferation hits and functional hits, which were able to promote the differentiation of iPSCs and the maturation of resulted hepatocyte-like cells. Improved directed redifferentiation using small molecules can improve results on a cost-benefit basis in large-scale applications.

\section{Transplantation of Redifferentiated Cells in Liver Therapy}

The liver cell therapy procedure involves direct injection of prepared isolated cells into portal vein or spleen (43) or transplantation of in vitro developed tissue clusters (44). Special anatomic location of liver provides different ways for cell transplantation, including percutaneous and intravascular delivery through both portal vein and hepatic artery (45). However, studies on rat model suggest that hepatic sinusoidal delivery is the most effective approach for cell transplantation (46). Transplantation of hepatocytes under a low flow hepatic artery condition, accompanied with cellular attachment factors and extracellular matrix components, is another highthroughput strategy (47). Ideally, self-regenerating capacity of transplanted liver cells is critical for cell therapy in patients with liver failure. Guo et al. (48) conditioned mice by administration of retrosin, a cell cycle inhibitor, for arresting proliferation of native hepatocyte. After elimination of drug effects, a fresh 2 million $\beta$-galactosidase-labeled cell suspension was injected into the spleen pole. Donor cell proliferation was assessed after injection of three doses of $\mathrm{CCl}_{4}, 0.5 \mathrm{ml} / \mathrm{kg}$. An average 20\% repopulation of liver cells was recorded. More recently, post-surgery infusion of adult-derived human liver stem cells improved liver regeneration in a mouse model with $70 \%$ hepatectomy (49).

Overall, the application of stem cell technology in treatment of liver diseases is promising at present (50). Several gene-editing clinical trials have just been approved and will be started in 2017, promoting reprogrammed cell-based therapy $(51,52)$.

\section{Clinical examples}

\section{Inherent liver diseases}

A major indication for liver transplantation is inherent metabolic liver diseases in children (53). iPSC technology provides a unique method for designing patient- and disease-specific therapies (54). Yusa et al. (55) showed that a combination of iPSCs and a transposon-based vector technology results in biallelic correction of a point mutation in $\alpha 1$-antitrypsin gene which is responsible for $\alpha 1$-antitrypsin deficiency. Additionally, genetic correction of iPSCs in patients with Wilson's disease using a lenti-viral vector could reverse the functional 
genetic defect of Wilson's disease gene in vitro (56). In principle, genetic correction of patient-derived cells is plausible in inherent liver diseases with known mutations (Figure 3) (57).

\section{Liver failure}

Acute liver failure (ALF) and acute-on-chronic liver failure are two main indications for cell transplantation. iPSCs that are originated from these diseases can provide an unlimited cellular source (54). In vivo studies by Isobe et al. (58) showed that liver cells differentiated from iPSCs can save rodent from lethal drug-induced ALF. Indeed, transplanted cells exhibited proliferative and liver functional properties (59).

\section{Liver cirrhosis}

Because of inevitable hepatocellular damage and fibrosis of hepatic tissue in cirrhosis, therapies should mostly rely on replacement of damaged cells and fibrosis correction (54). Different studies have reported that iPSC-derived hepatocytes promote hepatic regeneration, decrease fibrosis, and stabilize chronic liver disease in mice model (59-61). Despite these advances, iPSC-derived hepatocytes can temporarily support liver function and are hardly able to regenerate the original structure of the liver and to eliminate collagen deposition (62). Thus, other strategies are needed to help liver structure regeneration in cirrhosis through reprogramming of fibrogenic cells or transplantation of liver tissue construct (62).

\section{Liver cancer}

It has been reported that downregulation of cyclin-dependent kinase inhibitor 1, an important cell cycle mediator, in pluripotent stem cells generated from patients with hepatocellular carcinoma can promote differentiation into normal human hepatoma-like cells (63). Furthermore, it was shown that inhibition of aldo-ketoreductase 1 member B10 promotes retinoic acid-induced differentiation. However, efficacy and patient specificity of the first-mentioned method seem to be higher, as it avoids the toxic effects of combination therapy (63). Lei et al. (64) also introduced a protocol for generating cytotoxic T lymphocytes from iPSCs as an unlimited cellular source in breast cancer therapy. In future, this strategy can be used as a novel method for liver cancer.

\section{Clinical limitations}

Using viral vectors for transducing Oct4, Sox2, Klf4, and cMyc is an exciting method for generating human iPSCs. Despite high efficacy of this procedure, there remain some critical limitations for the application of iPSCs in clinics (65). Applications of retroviral-generated iPSCs are limited because of the 1) integration of retroviral DNA into host genome with variable copy numbers which interfere with promoter elements, polyadenylation signals, and coding sequences, affecting transcription potency (20), and 2) loss of pluripotency potential because of low expression of exogenous
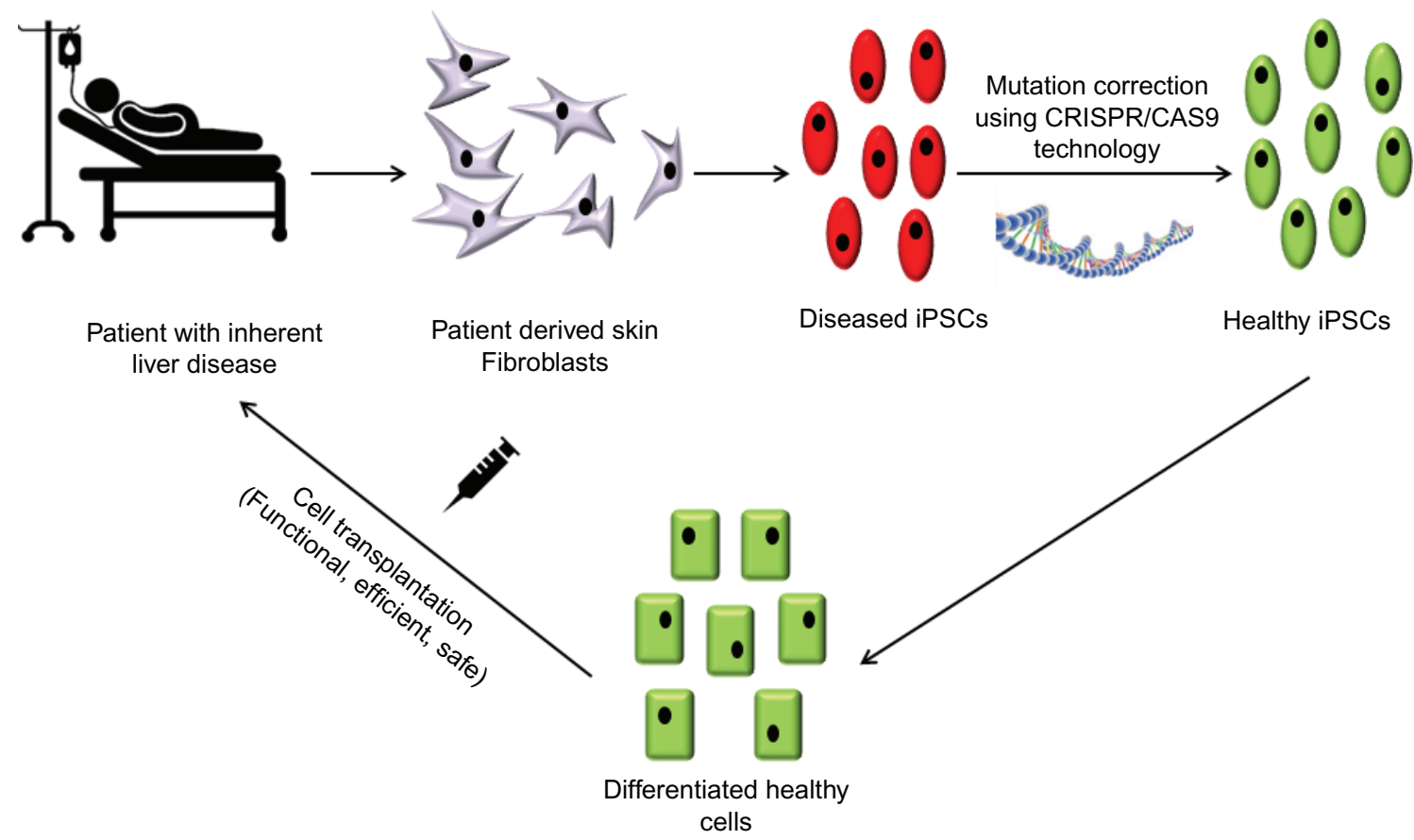

Figure 3. Clinical application of clustered regularly interspersed short palindromic repeats (CRISPR/Cas9). Skin fibroblasts from patient source can be dedifferentiated to pluripotent stem cells containing the disease causing mutation. This mutation can be corrected by CRISPR/Cas9 technology resulting in healthy stem cells which can be redifferentiated to patient-specific healthy cells for transplantation. 


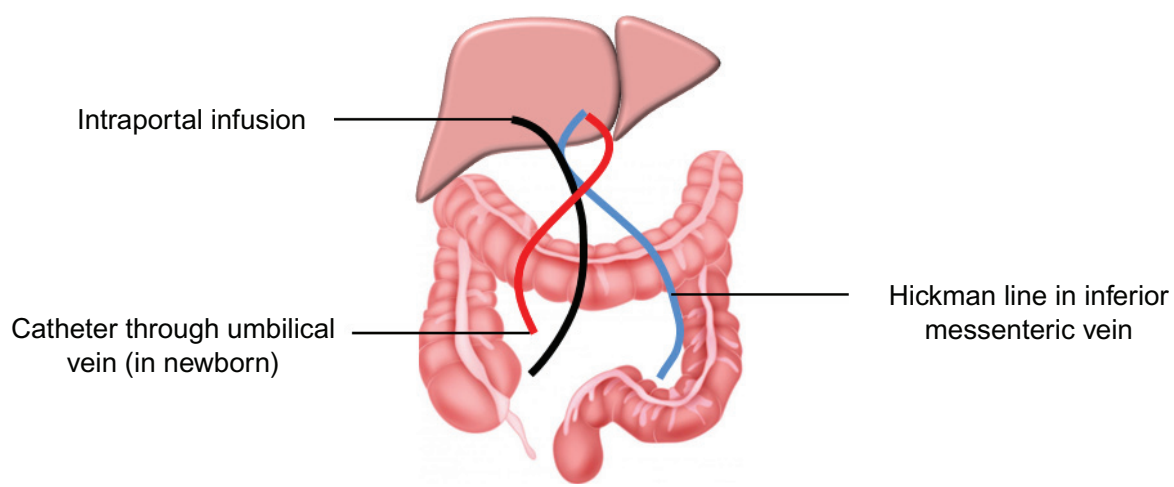

Figure 4. Liver cell transplantation routs. The portal circulation can pass directly infused cells to the liver tissue. The routine ways to directly access the portal circulation are percutaneous intraportal infusion, umbilical catheterization, and insertion of Hickman line in inferior mesenteric vein. The main concerns for transplantation of reprogrammed cells include using fresh or cryopreserved hepatocytes with cell viability of more than $60 \%$, a minimum of $10^{9}$ cell/infusion, and portal pressure monitoring (77).

Oct4, Sox2, Klf4, and c-Myc from viral constructs (66). Another critical concern is the exogenous genes itself; overexpression of Oct4, Sox2, Klf4, and c-Myc increases the chance of tumorigenesis $(66,67)$. Overexpression of Oct4 induces epithelial cell dysplasia (68). Sox 2 overexpression is also associated with serrated adenoma and mucinous colon carcinoma (69). Klf4 and c-Myc are also associated with breast cancer and some other human carcinomas (70). Tumor progression is also observed in murine chimeras after injection of retroviral-generated iPSCs to blastocysts which has been attributed to c-Myc overexpression $(71,72)$.

Despite gained advances in the differentiation of pluripotent stem cells into functional hepatocytes in vitro, production of primary adult hepatocytes that can proliferate in vivo still remains inaccessible $(73,74)$. The reason for this problem is that expansion and proliferation of transplanted cells need a tense sustain of hepatic cell mass (75). Furthermore, besides pluripotent stem cells-related problems, cell delivery complications are another important limiting factor of liver cell therapy. Direct injection of cells to liver parenchyma may increase the risk of cell entry to hepatic vein outflow and pulmonary vein, causing embolic complications (76). Injection of cells to hepatic or splenic artery, theoretically, also seems to be achievable. However, these methods may increase the risk of tissue necrosis due to embolic occlusion of vessels. In high blood flow condition, engrafted cells may be destroyed because of incoming mechanical forces (47). Furthermore, in portal hypertension and chronic liver diseases, the transplanted cell may be translocated to lungs through portosystemic collaterals or channels causing cardiovascular problems (Figure 4) (45,77). Therefore, there is an urgent need for clinical trial designing for the application of successful cell delivery methods to liver sinusoids. Obviously, standards of professional practice play an important role in the clinical setting. There is no international standard for reprogrammed liver cell therapy, as cell therapy in general has been limited to heterologous primary cells with resource scarcity and little satisfactory outcome.
The major obstacle in hepatocyte transplantation is poor engraftment results, encouraging researchers to suggest new strategies. Prominent among these are modifying metabolic status in the recipients of liver cell therapy (78) and cotransplantation of mesenchymal stem cells (79) because of their significant effects on liver regeneration and repair.

\section{Conclusion}

The restoration of hepatic function by patient-specific cell transplantation remains a promising strategy for liver therapy. Reprogramming strategy exploits preexisting somatic cells to produce other mature cell types or progenitors. The cornerstone of this strategy is to keep the cellular genome stability during dedifferentiation and efficient redifferentiation. Patient-derived hepatic cells can be transplanted directly in the form of isolated cells or as in vitro-generated liver tissue constructs. Animal model data suggest that liver tissue constructs may offer better regeneration and improved survival, but teratoma formation and rejection by immune system are observed in both strategies. These occur primarily due to the presence of residual undifferentiated cells in hepatocytes derived from human iPSCs. As a part of efforts toward translation of cell reprogramming science into clinical practice, more careful cell selection strategies should be integrated into improvement of dedifferentiation and redifferentiation protocols, especially in precision medicine where gene correction is needed. Furthermore, advances in cellular reprogramming highlight the need for developing and evaluating novel standards addressing clinical research interests in this field.

\section{Acknowledgments}

The research was financially supported by grants from the Stem Cell Research Center at Tabriz University of Medical Sciences and Iranian Council for Development of Stem Cell Sciences and Technologies. The authors would like to thank the Liver and Gastrointestinal Diseases Research Center at 
Tabriz University of Medical Sciences for support of this work. The authors express acknowledgements to their many colleagues whose related contribution was not cited here.

\section{Conflict of interest}

The authors declare no conflicts of interest with respect to research, authorship, and/or publication of this article.

\section{References}

1. Yu Y, Fisher JE, Lillegard JB, Rodysill B, Amiot B, Nyberg SL. Cell therapies for liver diseases. Liver Transpl. 2012;18(1):9-21. http://dx.doi.org/10.1002/1t.22467

2. Ellis AJ, Hughes RD, Wendon JA, Dunne J, Langley PG, Kelly JH, et al. Pilot-controlled trial of the extracorporeal liver assist device in acute liver failure. Hepatology. 1996;24(6): 1446-51. http://dx.doi.org/10.1002/hep.510240625

3. Chen Y, Li J, Liu X, Zhao W, Wang Y, Wang X. Transplantation of immortalized human fetal hepatocytes prevents acute liver failure in 90\% hepatectomized mice. Transplant Proc. 2010; 42: 1907-14. http://dx.doi.org/10.1016/j.transproceed.2010.01.061

4. Zaret KS, Grompe M. Generation and regeneration of cells of the liver and pancreas. Science. 2008;322(5907):1490-4. http:// dx.doi.org/10.1126/science.1161431

5. Li H, Zhang B, Lu Y, Jorgensen M, Petersen B, Song S. Adipose tissue-derived mesenchymal stem cell-based liver gene delivery. J Hepatol. 2011;54(5):930-8. http://dx.doi.org/10.1016/j.jhep. 2010.07.051

6. Piscaglia AC, Campanale M, Gasbarrini A, Gasbarrini G. Stem cell-based therapies for liver diseases: State of the art and new perspectives. Stem Cells Int. 2010;2010:259461. http://dx.doi. org/10.4061/2010/259461

7. Si-Tayeb K, Noto FK, Nagaoka M, Li J, Battle MA, Duris C, et al. Highly efficient generation of human hepatocyte-like cells from induced pluripotent stem cells. Hepatology. 2010;51 (1):297-305. http://dx.doi.org/10.1002/hep.23354

8. Ramesh T, Lee S-H, Lee C-S, Kwon Y-W, Cho H-J. Somatic cell dedifferentiation/reprogramming for regenerative medicine. Int $\mathbf{J}$ Stem Cells. 2009;2(1):18. http://dx.doi.org/10.15283/ijsc.2009.2. 1.18

9. Brambrink T, Hochedlinger K, Bell G, Jaenisch R. ES cells derived from cloned and fertilized blastocysts are transcriptionally and functionally indistinguishable. Proc Natl Acad Sci U S A. 2006;103(4): 933-8. http://dx.doi.org/10.1073/pnas.0510485103

10. Cowan CA, Atienza J, Melton DA, Eggan K. Nuclear reprogramming of somatic cells after fusion with human embryonic stem cells. Science. 2005;309(5739):1369-73. http://dx.doi.org/ 10.1126/science. 1116447

11. Håkelien A-M, Landsverk HB, Robl JM, Skålhegg BS, Collas P. Reprogramming fibroblasts to express T-cell functions using cell extracts. Nat Biotechnol. 2002;20(5):460-6. http://dx.doi.org/10. 1038/nbt0502-460

12. Taranger CK, Noer A, Sørensen AL, Håkelien A-M, Boquest AC, Collas P. Induction of dedifferentiation, genomewide transcriptional programming, and epigenetic reprogramming by extracts of carcinoma and embryonic stem cells. Mol Biol Cell. 2005;16(12):5719-35. http://dx.doi.org/10.1091/mbc. E05-06-0572

13. Bru T, Clarke C, McGrew MJ, Sang HM, Wilmut I, Blow JJ. Rapid induction of pluripotency genes after exposure of human somatic cells to mouse ES cell extracts. Exp Cell Res. 2008;314 (14):2634-42. http://dx.doi.org/10.1016/j.yexcr.2008.05.009

14. Takahashi K, Yamanaka S. Induction of pluripotent stem cells from mouse embryonic and adult fibroblast cultures by defined factors. Cell. 2006;126(4):663-76. http://dx.doi.org/10. 1016/j.cell.2006.07.024

15. Kim JB, Greber B, Araúzo-Bravo MJ, Meyer J, Park KI, Zaehres $\mathrm{H}$, et al. Direct reprogramming of human neural stem cells by OCT4. Nature. 2009;461(7264):649-3. http://dx.doi. org/10.1038/nature08436. PubMed PMID: 19718018.

16. Takebe T, Sekine K, Enomura M, Koike H, Kimura M, Ogaeri $\mathrm{T}$, et al. Vascularized and functional human liver from an iPSC-derived organ bud transplant. Nature. 2013;499(7459): 481-4. http://dx.doi.org/10.1038/nature12271

17. Hansel MC, Davila JC, Vosough M, Gramignoli R, Skvorak KJ, Dorko K, et al. The use of induced pluripotent stem cells for the study and treatment of liver diseases. Curr Protoc Toxicol. 2016;67:14.3.1-13.27. http://dx.doi.org/10.1002/0471140856. tx1413s67. PubMed PMID: 26828329; PubMed Central PMCID: PMCPMC4795152.

18. Goldman O, Gouon-Evans V. Human pluripotent stem cells: Myths and future realities for liver cell therapy. Cell Stem Cell. 2016;18(6):703-6. http://dx.doi.org/10.1016/j.stem.2016.05.019. PubMed PMID: 27257759.

19. Bassuk AG, Zheng A, Li Y, Tsang SH, Mahajan VB. Precision medicine: Genetic repair of retinitis pigmentosa in patientderived stem cells. Sci Rep. 2016;6:19969. http://dx.doi.org/10. 1038/srep19969

20. Takahashi K, Tanabe K, Ohnuki M, Narita M, Ichisaka T, Tomoda $\mathrm{K}$, et al. Induction of pluripotent stem cells from adult human fibroblasts by defined factors. Cell. 2007;131(5): 861-72. http://dx.doi.org/10.1016/j.cell.2007.11.019

21. Jinek M, Chylinski K, Fonfara I, Hauer M, Doudna JA, Charpentier E. A programmable dual-RNA-guided DNA endonuclease in adaptive bacterial immunity. Science. 2012;337 (6096):816-21. http://dx.doi.org/10.1126/science.1225829

22. $\mathrm{Hu} \mathrm{C}, \mathrm{Li} \mathrm{L}$. In vitro culture of isolated primary hepatocytes and stem cell-derived hepatocyte-like cells for liver regeneration. Protein Cell. 2015;6(8):562-74. http://dx.doi.org/10.1007/s13238015-0180-2

23. Han S, Bourdon A, Hamou W, Dziedzic N, Goldman O, Gouon-Evans V. Generation of functional hepatic cells from pluripotent stem cells. J Stem Cell Res Ther. 2012;10(8):1-7. http://dx.doi.org/10.4172/2157-7633.s10-008

24. Cai J, Zhao Y, Liu Y, Ye F, Song Z, Qin H, et al. Directed differentiation of human embryonic stem cells into functional hepatic cells. Hepatology. 2007;45(5):1229-39. http://dx.doi. org/10.1002/hep.21582

25. Liu H, Ye Z, Kim Y, Sharkis S, Jang YY. Generation of endoderm-derived human induced pluripotent stem cells from primary hepatocytes. Hepatology. 2010;51(5):1810-9. http://dx. doi.org/10.1002/hep.23626

26. Agarwal S, Holton KL, Lanza R. Efficient differentiation of functional hepatocytes from human embryonic stem cells. Stem Cells. 2008;26(5):1117-27. http://dx.doi.org/10.1634/stem cells.2007-1102

27. Liu H, Kim Y, Sharkis S, Marchionni L, Jang Y-Y. In vivo liver regeneration potential of human induced pluripotent stem cells from diverse origins. Sci Transl Med. 2011;3(82):82ra39. http:// dx.doi.org/10.1126/scitranslmed.3002376

28. Hay DC, Fletcher J, Payne C, Terrace JD, Gallagher RC, Snoeys J, et al. Highly efficient differentiation of hESCs to functional hepatic endoderm requires ActivinA and Wnt3a signaling. 
Proc Natl Acad Sci U S A. 2008;105(34):12301-6. http://dx.doi. org/10.1073/pnas.0806522105

29. Morrison GM, Oikonomopoulou I, Migueles RP, Soneji S, Livigni A, Enver T, et al. Anterior definitive endoderm from ESCs reveals a role for FGF signaling. Cell Stem Cell. 2008; 3(4):402-15. http://dx.doi.org/10.1016/j.stem.2008.07.021

30. Gouon-Evans V, Boussemart L, Gadue P, Nierhoff D, Koehler CI, Kubo A, et al. BMP-4 is required for hepatic specification of mouse embryonic stem cell-derived definitive endoderm. Nat Biotechnol. 2006;24(11):1402-11. http://dx.doi.org/10. 1038/nbt1258

31. Schmidt C, Bladt F, Goedecke S, Brinkmann V, Zschiesche W, Sharpe M, et al. Scatter factor/hepatocyte growth factor is essential for liver development. Nature. 1995;373(6516):699-702. http://dx.doi.org/10.1038/373699a0

32. Touboul T, Hannan NR, Corbineau S, Martinez A, Martinet C, Branchereau $\mathrm{S}$, et al. Generation of functional hepatocytes from human embryonic stem cells under chemically defined conditions that recapitulate liver development. Hepatology. 2010;51(5): 1754-65. http://dx.doi.org/10.1002/hep.23506

33. Kamiya A, Kinoshita T, Ito Y, Matsui T, Morikawa Y, Senba E, et al. Fetal liver development requires a paracrine action of oncostatin $\mathrm{M}$ through the gp130 signal transducer. EMBO J. 1999;18(8):2127-36. http://dx.doi.org/10.1093/emboj/18.8.2127

34. Rahimi Y, Mehdizadeh A, Nozad Charoudeh H, Nouri M, Valaei K, Fayezi S, et al. Hepatocyte differentiation of human induced pluripotent stem cells is modulated by stearoyl-CoA desaturase 1 activity. Dev Growth Differ. 2015;57(9):667-74. http://dx.doi.org/10.1111/dgd.12255. PubMed PMID: 26676854.

35. Takayama K, Inamura M, Kawabata K, Katayama K, Higuchi $\mathrm{M}$, Tashiro K, et al. Efficient generation of functional hepatocytes from human embryonic stem cells and induced pluripotent stem cells by HNF4 $\alpha$ transduction. Mol Ther. 2012;20(1):12737. http://dx.doi.org/10.1038/mt.2011.234

36. Takayama $\mathrm{K}$, Inamura $\mathrm{M}$, Kawabata $\mathrm{K}$, Tashiro $\mathrm{K}$, Katayama K, Sakurai F, et al. Efficient and directive generation of two distinct endoderm lineages from human ESCs and iPSCs by differentiation stage-specific SOX17 transduction. PLoS One. 2011;6(7):e21780. http://dx.doi.org/10.1371/journal. pone. 0021780

37. Kretsovali A, Hadjimichael C, Charmpilas N. Histone deacetylase inhibitors in cell pluripotency, differentiation, and reprogramming. Stem Cells Int. 2012;2012:184154. http://dx.doi.org/ $10.1155 / 2012 / 184154$

38. Ren M, Yan L, Shang CZ, Cao J, Lu LH, Min J, et al. Effects of sodium butyrate on the differentiation of pancreatic and hepatic progenitor cells from mouse embryonic stem cells. J Cell Biochem. 2010;109(1):236-44.

39. Zhou QJ, Xiang LX, Shao JZ, Hu RZ, Lu YL, Yao H, et al. In vitro differentiation of hepatic progenitor cells from mouse embryonic stem cells induced by sodium butyrate. $\mathbf{J}$ Cellular Biochem. 2007;100(1):29-42. http://dx.doi.org/10.1002/ jcb. 20970

40. Siller R, Greenhough S, Naumovska E, Sullivan GJ. Smallmolecule-driven hepatocyte differentiation of human pluripotent stem cells. Stem Cell Reports. 2015;4(5):939-52. http://dx.doi. org/10.1016/j.stemcr.2015.04.001

41. Zhu S, Rezvani M, Harbell J, Mattis AN, Wolfe AR, Benet LZ, et al. Mouse liver repopulation with hepatocytes generated from human fibroblasts. Nature. 2014;508(7494):93-7. http://dx.doi. org/10.1038/nature13020

42. Shan J, Schwartz RE, Ross NT, Logan DJ, Thomas D, Duncan SA, et al. Identification of small molecules for human hepatocyte expansion and iPS differentiation. Nat Chem Biol. 2013;9(8): 514-20. http://dx.doi.org/10.1038/nchembio.1270

43. Wertheim JA, Baptista PM, Soto-Gutierrez A. Cellular therapy and bioartificial approaches to liver replacement. Curr Opin Organ Transplant. 2012;17(3):235. http://dx.doi.org/10.1097/ MOT.0b013e3283534ec9

44. Bao J, Shi Y, Sun H, Yin X, Yang R, Li L, et al. Construction of a portal implantable functional tissue-engineered liver using perfusion-decellularized matrix and hepatocytes in rats. Cell Transplant. 2011;20(5):753-66. http://dx.doi.org/10.3727/ 096368910X536572. PubMed PMID: 21054928.

45. Forbes SJ, Gupta S, Dhawan A. Cell therapy for liver disease: From liver transplantation to cell factory. J Hepatol. 2015; 62(1):S157-69. http://dx.doi.org/10.1016/j.jhep.2015.02.040

46. Gupta S, Rajvanshi P, Sokhi R, Slehria S, Yam A, Kerr A, et al. Entry and integration of transplanted hepatocytes in rat liver plates occur by disruption of hepatic sinusoidal endothelium. Hepatology. 1999;29(2):509-19. http://dx.doi.org/10.1002/hep. 510290213

47. Gupta S, Lee CD, Vemuru RP, Bhargava KK. 111Indium labeling of hepatocytes for analysis of short-term biodistribution of transplanted cells. Hepatology. 1994;19(3):750-7. http://dx.doi. org/10.1002/hep.510290213

48. Guo D, Fu T, Nelson JA, Superina RA, Soriano HE. Liver repopulation after cell transplantation in mice treated with retrorsine and carbon tetrachloride1. Transplantation. 2002;73(11): 1818-24. http://dx.doi.org/10.1097/00007890-200206150-00020

49. Herrero A, Prigent J, Lombard C, Rosseels V, DaujatChavanieu M, Breckpot K, et al. Adult-derived human liver stem/progenitor cells infused 3 days post-surgery improve liver regeneration in a mouse model of extended hepatectomy. Cell Transplant. 2016; ahead of print. http://dx.doi.org/10.3727/ 096368916X692960. PubMed PMID: 27657746.

50. Trounson A, DeWitt ND. Pluripotent stem cells progressing to the clinic. Nat Rev Mol Cell Biol. 2016;17(3):194-200. http:// dx.doi.org/10.1038/nrm.2016.10

51. Cyranoski D. Chinese scientists to pioneer first human CRISPR trial. Nature. 2016;535(7613):476-7. http://dx.doi.org/10.1038/ nature.2016.20302. PubMed PMID: 27466105.

52. Deng P, Torrest A, Pollock K, Dahlenburg H, Annett G, Nolta JA, et al. Clinical trial perspective for adult and juvenile Huntington's disease using genetically-engineered mesenchymal stem cells. Neural Regen Res. 2016;11(5):702-5. http://dx.doi. org/10.4103/1673-5374.182682. PubMed PMID: 27335539; PubMed Central PMCID: PMCPMC4904446.

53. Fox IJ, Chowdhury JR, Kaufman SS, Goertzen TC, Chowdhury NR, Warkentin PI, et al. Treatment of the Crigler-Najjar syndrome type I with hepatocyte transplantation. N Engl J Med. 1998;338(20):1422-7. http://dx.doi.org/10.1056/ NEJM199805143382004

54. Yu Y, Wang X, Nyberg SL. Application of induced pluripotent stem cells in liver diseases. Cell Med. 2014;7(1):1-13. http://dx. doi.org/10.3727/215517914X680056

55. Yusa K, Rashid ST, Strick-Marchand H, Varela I, Liu PQ, Paschon DE, et al. Targeted gene correction of $\alpha 1$-antitrypsin deficiency in induced pluripotent stem cells. Nature. 2011;478 (7369):391-4. http://dx.doi.org/10.1038/nature10424

56. Zhang S, Chen S, Li W, Guo X, Zhao P, Xu J, et al. Rescue of ATP7B function in hepatocyte-like cells from Wilson's disease induced pluripotent stem cells using gene therapy or the chaperone drug curcumin. Hum Mol Genet. 2011;20(16):3176-87. http://dx.doi.org/10.1093/hmg/ddr223 
57. Chun YS, Chaudhari P, Jang Y-Y. Applications of patient-specific induced pluripotent stem cells; focused on disease modeling, drug screening and therapeutic potentials for liver disease. Int $\mathbf{J}$ Biol Sci. 2010;6(7):796-805. http://dx.doi.org/10.7150/ijbs.6.796

58. Isobe $\mathrm{K}$, Cheng Z, Ito S, Nishio N. Aging in the mouse and perspectives of rejuvenation through induced pluripotent stem cells (iPSCs). Results Probl Cell Differ. 2012;55:413-27. http://dx.doi. org/10.1007/978-3-642-30406-4_21

59. Espejel S, Roll GR, McLaughlin KJ, Lee AY, Zhang JY, Laird DJ, et al. Induced pluripotent stem cell-derived hepatocytes have the functional and proliferative capabilities needed for liver regeneration in mice. J Clin Invest. 2010;120(9): 3120-6. http://dx.doi.org/10.1172/JCI43267

60. Asgari S, Moslem M, Bagheri-Lankarani K, Pournasr B, Miryounesi M, Baharvand H. Differentiation and transplantation of human induced pluripotent stem cell-derived hepatocyte-like cells. Stem Cell Rev Rep. 2013;9(4):493-504. http://dx.doi.org/10. 1007/s12015-011-9330-y

61. Choi SM, Kim Y, Liu H, Chaudhari P, Ye Z, Jang Y-Y. Liver engraftment potential of hepatic cells derived from patient-specific induced pluripotent stem cells. Cell Cycle. 2011;10(15): 2423-7. http://dx.doi.org/10.4161/cc.10.15.16869

62. Chen Z, Qi L, Zeng R, Li HY, Dai LJ. Stem cells and hepatic cirrhosis. Panminerva Med. 2010;52(2):149-65.

63. Moriguchi H, Chung RT, Sato C. An identification of novel therapy for human hepatocellular carcinoma by using human induced pluripotent stem cells. Hepatology. 2010;51(3):1090-1.

64. Lei F, Zhao B, Haque R, Xiong X, Budgeon L, Christensen ND, et al. In vivo programming of tumor antigen-specific $\mathrm{T}$ lymphocytes from pluripotent stem cells to promote cancer immunosurveillance. Cancer Res. 2011;71(14):4742-7. http://dx.doi.org/10. 1158/0008-5472.CAN-11-0359

65. Medvedev SP, Shevchenko AI, Zakian SM. Induced pluripotent stem cells: Problems and advantages when applying them in regenerative medicine. Acta Naturae. 2010;2(2):18-28.

66. Okita K, Ichisaka T, Yamanaka S. Generation of germline-competent induced pluripotent stem cells. Nature. 2007;448(7151): 313-7. http://dx.doi.org/10.1038/nature05934

67. Carey BW, Markoulaki S, Hanna J, Saha K, Gao Q, Mitalipova M, et al. Reprogramming of murine and human somatic cells using a single polycistronic vector. Proc Natl Acad Sci U S A. 2009;106(1):157-62. http://dx.doi.org/10.1073/ pnas.0811426106

68. Hochedlinger K, Yamada Y, Beard C, Jaenisch R. Ectopic expression of Oct-4 blocks progenitor-cell differentiation and causes dysplasia in epithelial tissues. Cell. 2005;121(3):465-77. http://dx.doi.org/10.1016/j.cell.2005.02.018
69. Park ET, Gum JR, Kakar S, Kwon SW, Deng G, Kim YS. Aberrant expression of SOX2 upregulates MUC5AC gastric foveolar mucin in mucinous cancers of the colorectum and related lesions. Int J Cancer. 2008;122(6):1253-60. http://dx. doi.org/10.1002/ijc.23225

70. McConnell BB, Ghaleb AM, Nandan MO, Yang VW. The diverse functions of Krüppel-like factors 4 and 5 in epithelial biology and pathobiology. Bioessays. 2007;29(6):549-57. http:// dx.doi.org/10.1002/bies.20581

71. Okita K, Nakagawa M, Hyenjong H, Ichisaka T, Yamanaka S. Generation of mouse induced pluripotent stem cells without viral vectors. Science. 2008;322(5903):949-53. http://dx.doi.org/ 10.1126/science. 1164270

72. Duinsbergen D, Salvatori D, Eriksson M, Mikkers H. Tumors originating from induced pluripotent stem cells and methods for their prevention. Ann N Y Acad Sci. 2009;1176(1): 197-204. http://dx.doi.org/10.1111/j.1749-6632.2009.04563.x

73. Rashid ST, Corbineau S, Hannan N, Marciniak SJ, Miranda E, Alexander G, et al. Modeling inherited metabolic disorders of the liver using human induced pluripotent stem cells. J Clin Invest. 2010;120(9):3127-36. http://dx.doi.org/10.1172/JCI43122

74. Hashemi Goradel N, Darabi M, Shamsasenjan K, Ejtehadifar M, Zahedi S. Methods of liver stem cell therapy in rodents as models of human liver regeneration in hepatic failure. Adv Pharm Bull. 2015;5(3):293-8. http://dx.doi.org/10.5681/apb.2015.041. PubMed PMID: 26504749; PubMed Central PMCID: PMCPMC4616895.

75. Puppi J, Strom SC, Hughes RD, Bansal S, Castell JV, Dagher I, et al. Improving the techniques for human hepatocyte transplantation: Report from a consensus meeting in London. Cell Transplant. 2012;21(1):1-10. http://dx.doi.org/10.3727/ 096368911 X566208

76. Nagata H, Ito M, Shirota C, Edge A, McCowan TC, Fox IJ. Route of hepatocyte delivery affects hepatocyte engraftment in the spleen1. Transplantation. 2003;76(4):732-4. http://dx.doi. org/10.1097/01.TP.0000081560.16039.67

77. Kirk AD, Knechtle SJ, Larsen CP, Madsen JC, Pearson TC, Webber SA. Textbook of organ transplantation set. Hoboken, NJ: John Wiley \& Sons; 2014.

78. Hashemi Goradel N, Eghbal MA, Darabi M, Roshangar L, Asadi M, Zarghami N, et al. Improvement of liver cell therapy in rats by dietary stearic acid. Iran Biomed J. 2016;20(4): 217-22.PubMed PMID: 27090202; PubMed Central PMCID: PMCPMC4983676.

79. Liu T, Wang Y, Tai G, Zhang S. Could co-transplantation of iPS cells derived hepatocytes and MSCs cure end-stage liver disease? Cell Biol Int. 2009;33(11):1180-3. http://dx.doi.org/10. 1016/j.cellbi.2009.08.007 